\title{
The knowledge and practice of self-care management among patients attending a diabetes clinic in Kigali, Rwanda
}

\author{
Madeleine Mukeshimana ${ }^{1 *}$, Gregoire Hakizimana ${ }^{2}$, Clarisse Mwali ${ }^{2}$, Clemantine Umuhoza ${ }^{2}$, \\ Jocelyne Uwambajimana ${ }^{2}$, Domina Asingizwe ${ }^{3}$ \\ ${ }^{1}$ College of Medicine and Health Sciences, University of Rwanda \\ ${ }^{2}$ Department of General Nursing Graduates, College of Medicine and Health Sciences \\ ${ }^{3}$ Directorate of Research and Postgraduate Studies, College of Medicine and Health Sciences
}

\begin{abstract}
Background: Self-care management in diabetic patients is crucial to control and prevent associated complications. Diabetes complications are still highly prevalent and are mostly attributed to the lack of self-care knowledge and practices. Methods: A descriptive cross-sectional design approach explored self-care knowledge and practice among 80 participants attending a diabetes clinic in Kigali in 2011. Data were collected using a self-administered questionnaire that assessed 4 levels of diabetes self-care knowledge and practices which are respectively diet, blood glucose monitoring, physical activities and foot care. Results: Participants had a self-care knowledge gap in some areas of diabetes self- management. As many as 54.9\% $(n=44)$ of participants did not know the frequency of blood sugar testing; $63.7 \%(n=51)$ did not know the importance of snack/meal before exercising and $70 \%(n=56)$ among them were not taking a snack/meal before exercising. The participants experienced some complications: feet problems 88.7\% $(n=71)$; retinopathy 15\% $(n=12)$; hypertension 23.7\% $(n=19)$ and kidney diseases $8.7 \%(n=7)$. Conclusion: There were self-care knowledge and practice gaps in some areas of diabetes self-care management. Health care providers, particularly nurses should play a key role in providing with accurate information on diabetes self-care.
\end{abstract}

Key words: Diabetes, Self-care knowledge, self-care management

\section{Introduction}

Diabetes is one of the chronic diseases that affect both young and old people worldwide. The World Health Organisation (WHO) estimates that 171 million people suffer from diabetes in the world and it is more prevalent in developed countries (WHO, 2006). The American Diabetes Association shows that there were about 20.8 million people living with diabetes in United States alone, while in developing countries; the prevalence is expected to increase especially in Africa (ADA, 2006). The traditional lifestyle in Africa was characterized by regular and vigorous physical activity accompanied by subsistence on high fibre, whole grain-based diet rich in vegetables and fruits which contribute to the less chance of getting diabetes (WHO, 2006). However, urbanization has resulted in over-reliance on motorized transport and consumption of unhealthy diets rich in carbohydrates, fats, sugars and salts, which are diabetes risk factors (Christensen et al., 2009; IDF, 2003).

Diabetes as a chronic disease requires patients' involvement in their own self-care (Mehta, Karki, \& Sharma, 2006). For effective self-care, patients need accurate information on self-care information (Iwueze, 2007). Adequate self-care is associated with positive outcomes in slowing down the development and progression of complications of diabetes (Karam, Samir, Trupti, \& Sameer, 2012). However, the literature documents that diabetes complications are still increasing due to non-compliance with the medical regiment and lack of self-care management (Kleinbeck \& Williams, 2004). Different factors can explain the reasons for noncompliance and poor self-care including lack of resources. However, inadequate knowledge may also contribute. Information on how to engage in self-care comes from different sources including health care providers. However, there is no study on the accuracy and content of self-care that has been reported in Rwanda. The lack of such evidence might hinder efforts to address self-care management concerns and the designing of interventions to improve self-care management. The purpose of this study was to explore self-care knowledge and practices in diabetic adults in Rwanda.

*Corresponding author: angemado@gmail.com 


\section{Methods}

The cross-sectional study was carried out in 2011 at a diabetes clinic in Kigali in which 100 diabetic patients had registered. The clinic provided consultation to outpatients, hospitalization, minor surgery, pharmacy and laboratory services. Likewise, before consultations began, a nurse educated about 20-25 diabetes patients monthly on matters of self-care. A total of 80 patients aged 18 years and above who had diabetes type 1 or type 2 for at least one-year were selected from the 100 who had agreed to participate. The sample size was estimated by using the Raosoft sample size calculator (Raosoft Sample size calculator, 2004)

Data was collected by using a self-administered questionnaire comprising of 38 items. The author developed the tool based on the literature and the Michigan Diabetes and Research Training questionnaire (Michigan, 2015). The tool had four main sections covering socialdemographic data, participants' knowledge of self-care, presence of diabetes complications, and sources of selfcare information. For the content validity of the tool, a consensus validation approach was used. To ensure the reliability, the questionnaire was pre-tested with ten people from the same clinic. The test-retest reliability coefficient was 0.80 meaning that the tool was reliable (Litwin, 2003)

The clinic management team invited potential participants to come and meet the researchers once after a teaching session at the clinic during the four weeks of the study. The researchers approached the patients as a group, and explained to them the purpose of the study, following which they were asked if they were willing to participate. Those who accepted were individually given the informed consent form to sign before the self administered questionnaire was issued to them. Questionnaire based interview approach was used on those unable to read. Data were double entered into the computer using SPSS ${ }^{\circledR}$ Statistics version 16, and cleaned before analysis was done. The analysis involved calculation of frequencies per variable, and using a 95\% confidnce limit for difference testing with a one way chisquare. Likewise, confidence intervals were calculated for the different estimates. The ethical clearance for the study was obtained from the former Kigali Health Institute Ethics Committee and permission to collect data was secured from the clinic.

\section{Results}

All the 80 participants completed the questionnaires making the response rate $100 \%$ (Table 1). The numbers of respondents less than 31 years of age and those aged 31 years and above were about the same. The same applied to numbers of males and females. Those with a secondary and primary school levels of education were almost equal in number but much more than those with primary or higher education. The patients who have lived with the diabetes for less than 5 years and those on insulin treatment were many more than the others.

Table 1. Socio demographic characteristics of the sample $(\mathrm{N}=80)$

\begin{tabular}{|c|c|c|c|c|c|}
\hline Characteristics & & Frequency & $\begin{array}{l}\text { Percentage } \\
(\%)\end{array}$ & $\begin{array}{c}95 \% \mathrm{CI} \\
(\%)\end{array}$ & $\begin{array}{l}\text { Chi-square } \\
\text { p-value }\end{array}$ \\
\hline \multirow{2}{*}{ Gender } & Male & 32 & 40.0 & $29.2-51.6$ & \multirow{2}{*}{0.0736} \\
\hline & Female & 48 & 60.0 & $48.4-70.8$ & \\
\hline \multirow[t]{2}{*}{ Age } & $18-30$ years & 39 & 48.8 & $37.4-60.2$ & \multirow[b]{2}{*}{0.82345} \\
\hline & 31 years \& above & 41 & 51.2 & $39.8-62.6$ & \\
\hline \multirow{4}{*}{ Level of education } & No schooling & 12 & 15.0 & $8.0-24.7$ & \multirow{4}{*}{0.00585} \\
\hline & Primary & 24 & 30.0 & $20.3-41.3$ & \\
\hline & Secondary & 31 & 38.7 & $28.1-50.3$ & \\
\hline & Higher level & 13 & 16.2 & $8.9-26.2$ & \\
\hline \multirow{2}{*}{ Duration of illness } & $<5$ years & 49 & 61.2 & $49.7-71.9$ & \multirow{2}{*}{0.0442} \\
\hline & $>5$ years & 31 & 38.7 & 28.150 .3 & \\
\hline \multirow{4}{*}{ Current treatment } & $\begin{array}{l}\text { Oral Hypoglycaemia } \\
\text { agent }\end{array}$ & 13 & 16.2 & $8.9-26.2$ & \multirow{4}{*}{$<0.001$} \\
\hline & Insulin injection & 59 & 73.7 & $63.7-82.9$ & \\
\hline & Insulin and oral agent & 5 & 6.2 & $2.1-14.0$ & \\
\hline & Diet and physical exercise & 3 & 3.7 & $0.78-10.6$ & \\
\hline
\end{tabular}

Knowledge and practice about five aspects of diabetes self-care management

The results for the knowledge about aspects of self-care (Table 2) have shown that the majority $88.7 \%(n=71)$ of the respondents had knowledge of the normal range of blood glucose $(60-120 \mathrm{mg} / \mathrm{dl}$ or $72-126 \mathrm{mg} / \mathrm{dl})$. However, there was a variation in their understanding of frequency of testing for sugar level, of which the overall results show that $59 \%(n=44)$ did not understand the frequency for blood sugar testing. More than half of respondents 
$70 \%(\mathrm{n}=56)$ had adequate knowledge about diabetic meal content (Energy food 1/4; Proteins 1/4; Vegetables and fruit $1 / 2)$ and $58.7 \%(n=33)$ knew the recommended diabetic meals plan, that is breakfast, snack, lunch, snack, dinner, and snack. Most $(87.5 \% ; n=70)$ knew that they should not consume alcohol.

Table 2. Knowledge about diabetic self-care $(\mathbf{N}=80)$

\begin{tabular}{|c|c|c|c|c|c|}
\hline \multicolumn{2}{|l|}{ Knowledge indicators } & Frequency & $\%$ & $\begin{array}{l}95 \% \mathrm{CI} \\
(\%)\end{array}$ & $\begin{array}{l}\text { Chi-square } \\
\text { p-value }\end{array}$ \\
\hline \multicolumn{6}{|c|}{ Knowledge about blood glucose levels self-testing } \\
\hline Knowledge about normal & $72-126 \mathrm{mg} / \mathrm{dl}$ & 33 & 41.2 & $30.3-52.0$ & \multirow{5}{*}{$<0.001$} \\
\hline \multirow[t]{4}{*}{ range of glycaemia } & $\geq 70 \mathrm{mg} / \mathrm{ml}$ & 2 & 2.5 & $0.3-8.7$ & \\
\hline & $\leq 110 \mathrm{mg} / \mathrm{ml}$ & 3 & 3.7 & $0.78-10.6$ & \\
\hline & $60-120 \mathrm{mg} / \mathrm{ml}$ & 38 & 47.5 & $36.2-59.0$ & \\
\hline & No knowledge & 4 & 5.0 & $1.4-12.3$ & \\
\hline \multirow{3}{*}{$\begin{array}{l}\text { Knowledge about frequency } \\
\text { of self- testing for blood } \\
\text { sugar levels }\end{array}$} & Every day & 36 & 45.0 & $33.8-56.5$ & \multirow{3}{*}{0.004} \\
\hline & Twice a week & 13 & 16.2 & $8.9-26.2$ & \\
\hline & Once a month & 31 & 38.7 & $28.1-50.3$ & \\
\hline \multicolumn{6}{|c|}{ Knowledge about diabetic diet } \\
\hline \multirow[t]{3}{*}{ Daily meals plan } & Breakfast, Lunch, Dinner & 26 & 32.5 & $22.4-43.9$ & \multirow{3}{*}{0.2560} \\
\hline & $\begin{array}{l}\text { Breakfast, snack, lunch, } \\
\text { Dinner }\end{array}$ & 21 & 26.2 & $17.0-37.3$ & \\
\hline & $\begin{array}{l}\text { Breakfast, snack, lunch, } \\
\text { Snack, dinner, snack }\end{array}$ & 33 & 41.2 & $30.3-52.8$ & \\
\hline \multirow[t]{3}{*}{ Diabetic meal content } & $\begin{array}{l}\text { Energy food } 1 / 2 ; \text { Proteins }^{1} / 4 ; \\
\text { Vegetables and fruit } 1 / 4\end{array}$ & 13 & 16.3 & $8.9-26.2$ & \multirow{3}{*}{$<0.001$} \\
\hline & $\begin{array}{l}\text { Energy food } 1 / 4 ; \text { Proteins } \\
1 / 4 ; \text { Vegetables andfruit } 1 / 2\end{array}$ & 56 & 70.0 & $58.7-79.7$ & \\
\hline & $\begin{array}{l}\text { Energy food } 1 / 4 ; \text { Proteins }^{1 / 4} ; \\
\text { Vegetables and fruit } 1 / 4\end{array}$ & 11 & 13.7 & $7.1-23.3$ & \\
\hline \multirow[t]{2}{*}{ Alcohol consumption } & Yes & 10 & 12.5 & $6.16-21.8$ & \multirow{2}{*}{$<0.001$} \\
\hline & No & 70 & 87.5 & $78.2-93.8$ & \\
\hline \multicolumn{6}{|c|}{ Knowledge about regular physical exercise } \\
\hline \multirow{2}{*}{$\begin{array}{l}\text { Necessity to participate in } \\
\text { physical exercise }(N=80)\end{array}$} & Yes & 56 & 70.0 & $58.7-79.7$ & \multirow{2}{*}{$<0.001$} \\
\hline & No & 24 & 30.0 & $20.2-41.3$ & \\
\hline \multirow{6}{*}{$\begin{array}{l}\text { Frequency of doing physical } \\
\text { exercise in week }(\mathrm{N}=56)\end{array}$} & Once per week & 10 & 17.8 & $8.9-30.4$ & \multirow{6}{*}{0.00121} \\
\hline & Twice per week & 18 & 32.0 & $20.3-46.0$ & \\
\hline & 3times per week & 13 & 23.2 & $13.0-36.4$ & \\
\hline & 4times per week & 6 & 10.7 & $4.0-21.9$ & \\
\hline & 5 times per week & 9 & 16.0 & 7.6-28.3 & \\
\hline & Every day & 0 & 0.0 & - & \\
\hline \multirow{5}{*}{$\begin{array}{l}\text { Duration of staying in one } \\
\text { session }(\mathrm{N}=56)\end{array}$} & Less 15 minutes & 4 & 7.1 & $2.0-17.2$ & \multirow{5}{*}{0.00162} \\
\hline & 16-30 minutes & 17 & 30.3 & $18.8-44.1$ & \\
\hline & 31-45minutes & 20 & 35.7 & $23.3-49.6$ & \\
\hline & 46-60 minutes & 9 & 16.1 & $7.6-28.3$ & \\
\hline & Above 1hour & 6 & 10.7 & $4.0-21.9$ & \\
\hline \multicolumn{6}{|c|}{ Knowledge about foot care $(n=80)$} \\
\hline Inspection of the shoes & Yes & 55 & 68.8 & $57.4-78.6$ & \multirow{2}{*}{0.0008} \\
\hline before putting on & No & 25 & 31.2 & $21.3-42.6$ & \\
\hline \multirow{2}{*}{$\begin{array}{l}\text { Putting on the soaks before } \\
\text { putting on closed shoes }\end{array}$} & Yes & 40 & 50.0 & $38.6-61.4$ & \multirow{2}{*}{1.0} \\
\hline & No & 40 & 50.0 & $38.6-61.4$ & \\
\hline
\end{tabular}

There are participants who did not exercise $30 \%(n=24)$ while it is recommended for diabetic patients to exercise; also only $22.5 \%(n=18)$ exercised the minimum recommended three times a week and none of the participants exercised every day. Only few participants 35\% (n=28) stayed the recommended 31 to 45 minutes in one session of exercise. 
Only few participants at 30\% $(n=24)$ engaged in an important practice of taking food before exercising while 13.8\% $(\mathrm{n}=11)$ who were on insulinotherapy could not inject themselves. The majority of respondents at $78.8 \%(\mathrm{n}=63)$, checked their feet before putting on the shoes, and $63 \%(n=51)$ checked their feet every day as a matter of principle. These results are shown in Table 3.

Table 3. The practice about self-care $(\mathrm{N}=80)$

\begin{tabular}{|c|c|c|c|c|c|}
\hline Practice indicators & & Frequency & $\%$ & $\begin{array}{l}95 \% \mathrm{CI} \\
(\%)\end{array}$ & $\begin{array}{l}\text { Chi-square } \\
\text { p-value }\end{array}$ \\
\hline \multirow{2}{*}{ Do you exercise } & Yes & 56 & 70.0 & $58.7-79.7$ & \multirow{2}{*}{0.01} \\
\hline & No & 24 & 30.0 & $20.2-41.3$ & \\
\hline \multirow{5}{*}{$\begin{array}{l}\text { How many times a week do you } \\
\text { exercise }\end{array}$} & Once a week & 15 & 18.8 & $10.9-29.3$ & \multirow{5}{*}{0.0370} \\
\hline & Twice a week & 25 & 31.3 & $21.3-42.5$ & \\
\hline & 3 times a week & 18 & 22.5 & $13.9-33.2$ & \\
\hline & 4 times a week & 9 & 11.3 & $5.3-20.3$ & \\
\hline & 5 times a week & 13 & 16.3 & $8.9-26.2$ & \\
\hline \multirow{5}{*}{ How long do you stay in a session } & Less than 15 & 5 & 6.3 & $2.1-14.0$ & \multirow{5}{*}{$<0.001$} \\
\hline & minutes & 25 & 31.3 & $21.3-42.5$ & \\
\hline & 16-30 minutes & 28 & 35.0 & $24.7-46.5$ & \\
\hline & $\begin{array}{l}31-45 \text { minutes } \\
46-66 \text { minutes }\end{array}$ & 13 & 16.3 & $8.9-26.2$ & \\
\hline & $\begin{array}{l}\text { 40-60 minutes } \\
\text { Above } 1 \text { hour }\end{array}$ & 9 & 11.3 & $5.3-20.3$ & \\
\hline \multirow{2}{*}{ Do you take food before exercising } & Yes & 24 & 30.0 & $20.2-41.3$ & \multirow{2}{*}{$<0.001$} \\
\hline & No & 56 & 70.0 & $58.7-79.7$ & \\
\hline \multirow{2}{*}{$\begin{array}{l}\text { Do you check your feet for } \\
\text { abnormalities }\end{array}$} & Yes & 63 & 78.8 & $68.2-87.1$ & \multirow{2}{*}{$<0.001$} \\
\hline & No & 17 & 21.3 & $13.0-31.8$ & \\
\hline \multirow{4}{*}{ The frequency of checking your feet } & Every day & 51 & 63.8 & $52.2-74.2$ & \multirow{4}{*}{$<0.001$} \\
\hline & Once a week & 5 & 6.3 & $2.1-14.0$ & \\
\hline & Twice a week & 3 & 3.8 & $0.8-10.6$ & \\
\hline & Once a month & 4 & 5.0 & $1.4-12.3$ & \\
\hline
\end{tabular}

\section{Diabetes complications}

Many respondents had diabetes complications. About $50 \%(n=40)$ of the participants had a loss of consciousness; $89.0 \%(\mathrm{n}=71)$ had foot insensibility and a few, 23.7\% ( $\mathrm{n}=19)$, experienced hypertension (Table 4).

Table 4. Participants with diabetes complications $(\mathrm{N}=80)$

\begin{tabular}{|c|c|c|c|c|c|}
\hline Complications experienced & & Frequency & $\%$ & $\begin{array}{l}95 \% \mathrm{CI} \\
(\%)\end{array}$ & $\begin{array}{l}\text { Chi-square } \\
\text { p-value }\end{array}$ \\
\hline \multirow{2}{*}{ Loss of consciousness } & Yes & 40 & 50.0 & $38.6-61.4$ & \multirow[t]{2}{*}{1.0} \\
\hline & No & 40 & 50.0 & $38.6-61.4$ & \\
\hline \multirow{2}{*}{ Feet insensibility during touch } & Yes & 71 & 89.0 & $79.7-94.7$ & \multirow[t]{2}{*}{$<0.001$} \\
\hline & No & 9 & 11.2 & $5.3-20.3$ & \\
\hline \multirow{2}{*}{ Retinopathy case } & Yes & 12 & 15.0 & $8.0-24.7$ & \multirow[t]{2}{*}{$<0.001$} \\
\hline & $\mathrm{No}$ & 68 & 85.0 & $75.3-92.0$ & \\
\hline \multirow{2}{*}{ Hypertension case } & Yes & 19 & 23.7 & $14.9-34.6$ & \multirow[t]{2}{*}{$<0.001$} \\
\hline & $\mathrm{No}$ & 61 & 76.3 & $65.4-85.0$ & \\
\hline \multirow{2}{*}{ Kidney disease cases } & Yes & 7 & 8.7 & $3.6-17.2$ & \multirow[t]{2}{*}{$<0.001$} \\
\hline & No & 73 & 91.3 & $82.8-96.4$ & \\
\hline
\end{tabular}




\section{Sources of information}

The patients received information about diabetes self-care management from diverse sources: the doctors $(25 \%)$, nurses $(16.3 \%)$ or from both $(58.7 \%)$. They also received the information from workshops, books, internet, radio and television as shown in Table 5.

Table 5. Source of information about diabetic self care

\begin{tabular}{|c|c|c|c|c|c|}
\hline Source & & Frequency & $\%$ & $\begin{array}{l}95 \% \mathrm{CI} \\
(\%)\end{array}$ & $\begin{array}{l}\text { Chi-square } \\
\text { p-value }\end{array}$ \\
\hline \multirow{2}{*}{$\begin{array}{l}\text { Workshop about diabetic self-care } \\
(\mathbf{N}=\mathbf{8 0})\end{array}$} & Yes & 41 & 51.3 & $39.8-62.6$ & \multirow[t]{2}{*}{0.8234} \\
\hline & No & 39 & 48.7 & $37.4-60.2$ & \\
\hline \multirow{4}{*}{$\begin{array}{l}\text { Frequency of workshop per year } \\
(\mathbf{N}=41)\end{array}$} & Once a year & 3 & 7.3 & $1.5-19.9$ & \multirow{4}{*}{$<0.001$} \\
\hline & Twice a year & 5 & 12.2 & $4.1-26.2$ & \\
\hline & $\begin{array}{l}\text { Once in } 3 \\
\text { months }\end{array}$ & 31 & 75.6 & $59.7-87.6$ & \\
\hline & $\begin{array}{l}\text { Many more } \\
\text { times in a year }\end{array}$ & 2 & 4.9 & $0.6-16.5$ & \\
\hline \multirow{3}{*}{$\begin{array}{l}\text { Information about self-care from health } \\
\text { professionals } \\
(\mathbf{N}=\mathbf{8 0})\end{array}$} & Doctor & 20 & 25.0 & $16.0-35.9$ & \multirow[t]{3}{*}{$<0001$} \\
\hline & Nurse & 13 & 16.3 & $8.9-26.2$ & \\
\hline & $\begin{array}{l}\text { Both Doctors } \\
\text { and nurse }\end{array}$ & 47 & 58.7 & $47.2-69.6$ & \\
\hline \multirow{5}{*}{$\begin{array}{l}\text { Other sources of information about } \\
\text { diabetic self-care } \\
(\mathbf{N}=\mathbf{8 0})\end{array}$} & Radio & 19 & 23.7 & $14.9-34.6$ & \multirow[t]{5}{*}{$<0.01$} \\
\hline & Television & 17 & 21.3 & $12.9-31.8$ & \\
\hline & Internet & 27 & 33.7 & $23.5-45.2$ & \\
\hline & Books & 11 & 13.7 & $7.1-23.3$ & \\
\hline & All of them & 6 & 7.5 & $2.8-15.6$ & \\
\hline \multirow{2}{*}{ Attending workshop $(\mathbf{N}=\mathbf{8 0})$} & Yes & 41 & 51.3 & $39.8-62.6$ & \\
\hline & No & 39 & 48.7 & $37.4-60.2$ & \\
\hline
\end{tabular}

\section{Discussion}

The aim of the study was to assess knowledge of self-care practices among diabetic patients attending a diabetes clinic in Kigali. The results showed that participants had knowledge of some aspects of diabetes self-care, but also had a knowledge gap in others. For example the majority of respondents knew the importance of blood sugar testing, they also knew the normal range of blood glucose but some of them did not comply with the recommended frequency of testing for the blood sugar level every day once or twice for someone not using insulin and 4 to 5 times a day for those on insulin therapy. The study done in France on self-monitoring of blood glucose in diabetic patients found that, the frequency of testing was not daily but it varied with the reasons for doing so: $27.7 \%$ tested once or twice a day to make adjustments for food intake and $36.2 \%$ were testing three or more times a day to assess the impact of physical activity (ADA, 2009). However, in another study it was found that $24.1 \%$ of participants tested occasionally or less than once a month to make adjustments to food intake (Monnier, Colette, Lapinski, \& Boniface, 2004).

In the present study, $58 \%$ of respondents knew the recommended diabetic meal plan: Breakfast, snack, lunch, Snack, dinner, snack and more than half, $70 \%$, $(\mathrm{n}=56)$ knew the content of diabetic meal (Energy food $1 / 4$; Proteins $1 / 4$; Vegetables and fruit $1 / 2$ ). These findings did not agree with those from a study done by Okolie et al. (Okolie, Uchenna, Ijeoma, Ngozi, \& Kalu-Igwe, 2009) who found that only few (14.6\%) patients had good knowledge of the nutritional management, which is one of the important factors in self-care. The proportion of patients that responded positively to the option that they should eat a lot of whole grains, fresh vegetables and fruits was low. This probably showed lack of adequate knowledge of the value of fruits and vegetables. Whole grains and legumes fulfil the four dietary objectives for people with diabetes - high complex carbohydrates, high fibre, low fat and refined sugar (Khattab, Yousef, Khader, Abdelkarim, \& Kamel, 2010). Vegetables and fruits should be part of every meal of a diabetic patient. Another study done on factors associated with poor glycaemia control among patients with type 2 diabetes found that only a small percentage $(34.5 \%)$ of patients with diabetes were adherent to diet regimen (Khattab et al., 2010). Prevention of complications of diabetes involves complying with drug treatment and the diet regimen, as well as adapting simple health and self-care measures that prevent injury especially to the lower extremities of the body as well as maintain skin integrity. 
More than half of respondents $70 \%(\mathrm{n}=56)$ knew that it was important to exercise, however, few $2.5 \% \quad(n=18)$ participated in physical exercises three times a week and $28.7 \%(n=23)$ stayed in a session up to $30-45$ minutes. According to the (ADA, 2003) it is recommended that diabetic patients exercise at least three times a week and it is better to exercise every day and one session should last about 30 to 45 minutes. While it was not immediately clear why most patients did not engage in adequate physical exercises, many studies have reported high levels of noncompliance in physiotherapeutic exercises. Among the cited reasons to be influencing compliance were lack of time for exercises, not being ready to participate, perceives severity of the symptoms, co-morbidities, perceived effectiveness of the intervention, comparison with others and support from physiotherapists (Campbell, 2001). Encouragingly, two-thirds of the respondents were aware of importance of exercise, diet control and drug compliance (Dyuff, 2006).

The study done on factors associated with poor glycaemia control among patients with type 2 diabetes also found that $54.8 \%$ of patients with diabetes were participating in at least 30 minutes of physical exercise (ADA, 2009). These findings however, did not agree with Monnier et al. who found that only $7.3 \%$ engaged in regular exercise as self-care measures to prevent/control diabetes to avoid complications (Monnier et al., 2004). Exercise has a significant role in the regulation of blood glucose, improves insulin action, metabolism of proteins and fats and prevents complications of diabetes. Lack of understanding of the beneficial effects of exercise in the regulation of diabetes may lead to inappropriate treatment methods, an increase risk of complications and delay of the healing process.

Many participants $67.5 \%(\mathrm{n}=54) \mathrm{knew}$ that it is vital to inspect the shoes before putting on and a half of them agreed that they put on socks before putting on closed shoes. These results are in agreement with other studies that checking feet every day prevents foot problems, recognizes problems early, and seeks the right treatment when problems occur others (Desalu, Salawu, Jimoh, Adekoya, \& Busari, 2011). According to (ADA, 2003), it is necessary to inspect the shoes before putting them on to make sure that nothing has fallen into them that could hurt the feet.

\section{Diabetes complications}

Despite the young age of the participants and the relatively short disease duration, complications such as loss of consciousness hypertension, retinopathy, feet insensibility and kidney disease were reported. Lack of adequate self-care management, may have contributed to these complications. Research done in Australia where diabetes is a common underlying cause of death, common conditions listed as associated complications included coronary heart disease (64\% of cases), kidneyrelated diseases 32\%, heart failure 19\% and stroke 17\% (Bushfield \& Walker, 1986). Prevention of complications of diabetes involves complying with drug treatment and diet regimen, as well as adapting simple health and selfcare measures that prevent injury especially to the lower extremities of the body and maintaining skin integrity. From the results of the current study, it is clear that participants did not adequately comply with the selfcare management requirements designed to prevent the development of complications.

\section{Sources of information}

The results of this study found that participants got information from different resources. While nurses themselves were slightly less likely to be key informants they are the professionals who are most likely to be in frequent contact with patients. This highlights the need for nurses to be well-informed about diabetes self-care management and be able to teach this information to the patients. A study done in Nigeria on knowledge of diabetes management and control by diabetic patients found that nurses were the least likely, followed by the doctors, to give information to diabetic patients (Okolie et al., 2009) These findings are discouraging because doctors and nurses were the individuals with the greatest contact time with the patients. They are expected to take the lead in providing relevant information to the patient/client. However, according to Okolie this important aspect of service is not given the importance it deserves (Okolie et al., 2009). This agrees with others who stated that there is no concrete evidence to show that diabetic patients are periodically informed of the things they should do to be able to manage the disease (ADA, 2003). This finding is significant and implies that nurses and doctors, need to be more involved in information dissemination since they are strategic positioned.

Apart from the radio and television, the internet was found to be among the main sources of information on self-care practices. This is in agreement with the findings of other studies that social networks were significantly positively associated with the reduction of complication related to diabetes (Shaya et al., 2014).

\section{Conclusion}

The study revealed that participants had acceptable knowledge in some self-care areas. For instance, the majority reported adequately the normal range of blood sugar level, and the same applies to diabetic diet. In contrast, they missed the recommended frequency of blood sugar testing along with the daily diabetic meals plan. Participants recognized the importance of physical exercise. However, they were not aware of physical exercise duration and its frequency. The internet and other social networks can be a useful source of 
information on self-care. The study highlighted diabetes self-care management knowledge gaps, which may have contributed to the diabetes complications reported by participants.

\section{Recommendations}

There is a need for the diabetes clinic to monitor and evaluate the use of information received by their clients; nurses would be the first ones to give more explanation to the clients since they meet most often. The training workshops about self-care need to involve as many patients as possible and if feasible be a little more frequent. Studies on similar context but with wider scope and much larger sample size are recommended.

\section{Acknowledgements}

The authors are grateful to diabetic patients attending diabetes clinic in Kigali for their cooperation during period of data collection. The management of the clinic is appreciated for allowing the study to be done in their facility. Rwanda Educational Board (REB) for the financial support.

\section{Conflict of interest}

There is none.

\section{Authors`contributions}

MM: Played a major role in the conception, design, interpretation and writing of the manuscript, $\mathrm{GH}, \mathrm{CM}$, $\mathrm{JU}$ and $\mathrm{CU}$ played a major role in the conception, design and interpretation, DA: Played a significant role in editing the paper.

\section{References}

ADA. (2003). Implications of the United Kingdom Prospective Diabetes Study. Diabetes Care., 26, 28-32.

ADA. (2006). Nutrition recommendations and interventions for diabetes-2006: A position statement of the American Diabetes Association. Diabetes Care, 29(9), 2140-2157. doi:10.2337/dc06-9914

ADA. (2009). 2009. Standards of medical care in diabetes. Diabetes Care, 32(1), S17-S45.

Bushfield, R., \& Walker, R. (1986). Good Diabetic control: The Role of Patient's Perception and Beliefs. Engl. Diabetol. Journal., 5(3), 435-439.

Campbell, R. (2001). Why don't patients do their exercises? Understanding non-compliance with physiotherapy in patients with osteoarthritis of the knee. Journal of Epidemiology \& Community Health, 55(2), 132-138. doi:10.1136/ jech.55.2.132

Christensen, D. L., Friis, H., Mwaniki, D. L., Kilonzo, B., Tetens, I., Boit, M. K., Borch-Johnsen, K. (2009). Prevalence of glucose intolerance and associated risk factors in rural and urban populations of different ethnic groups in Kenya. Diabetes Research and Clinical Practice, 84(3), 303-310. doi:10.1016/j.diabres.2009.03.007

Desalu, F., Salawu, A., Jimoh, A., Adekoya, O., \& Busari. (2011). Self-reported knowledge and practice among patients attending three tertiary Hospitals in Nigeria. Ghana Medical Journal., 45(2), 61-64.

Dyuff, R. (2006). Complete Food and Nutrition Guide for Diabetes Patients. California: John Wiley and Sons In. 2.

IDF. (2003). Diabetes Atlas. 4thEdition. Brussels, Belgium.

Iwueze, J. (2007). Managing your Diabetes: Assessment and Management of Patients with Diabetes Mellitus. Owerri: Skill Mark Media Ltd.

Karam, P., Samir, D. B., Trupti, N. B., \& Sameer, V. (2012). Evaluation of knowledge and self-care practices in diabetic patients and their role in disease management. National Journal of Community Medicine, 3(1).

Khattab, M., Yousef, S., Khader, S., Abdelkarim, A., \& Kamel, A. (2010). Factors associated with poor glycemic control among patients with Type 2 diabetes. Journal of Diabetes and Its Complications., 24, 84-89.

Kleinbeck, C., \& Williams, A. (2004). Disabilities, diabetes, and devices. Home Healthcare Nurse, 22(7), 469-475.

Litwin, M. (2003). How to assess and interpret survey psychometrics. The Survey Kit -2nd Ed . London: Sage Publications.

Mehta, R. S., Karki, P., \& Sharma, S. K. (2006). Risk factors, associated health problems, reasons for admission and knowledge profile of diabetes patients admitted in BPKIHS. Kathmandu University Medical Journal, 4(1), 11-13. doi:10.4103/0973-3930.22775

Michigan, U. of. (2015). Michigan Diabetes Research and Training Center's Revised Diabetes Knowledge Test. Michigan: University of Michigan, 2015. Retrieved from http://www.med.umich.edu/mdrtc/profs/documents / svi/dkt5no_answers.pdf

Monnier, L., Colette, C., Lapinski, H., \& Boniface, H. (2004). Self-monitoring of blood glucosein diabetic patients:from the least common denominator to the greatest common multiple. Diabetes Metab, 30, 113-9.

Okolie, V., Uchenna, E., Ijeoma, I., Ngozi, P., \& Kalu-Igwe, I. (2009). Knowledge of diabetes management and control by diabetic patients at Federal Medical CentreUmuahiaAbia State, Nigeria. International Journal of Medicine and Medical Sciences., 1(9), 353-358.

Raosoft Sample size calculator (2004). Raosoft, Inc. Retrieved march 15, 2010 from: http://www.raosoft.com/samplesize. html. (n.d.).

Shaya, F. T., Chirikov, V. V, Howard, D., Foster, C., Costas, J., Snitker, S., ... Kucharski, K. (2014). Effect of social networks intervention in type 2 diabetes: a partial randomised study. Journal of Epidemiology \& Community Health, 68(4), 326-332. doi:10.1136/jech-2013-203274

WHO. (2006). Diabetes Mellitus. Epidemiol. 3. 